\title{
Study on Yongchang Guildhall of Qing Dynasty
}

\author{
Liqiong Tai \\ College of Humanities, Baoshan University, Baoshan Yunnan, 678000, China
}

Keywords: Qing Dynasty, Yongchang, Guildhall, Function.

\begin{abstract}
The Guildhall is a non-governmental organization set by geographically-linked persons in the same origin or persons in the same industry for the purpose of offering sacrifices, meeting and promoting business. In the Qing Dynasty, Yongchang was one of the four major commercial metropolises in Yunnan Province (Kunming, Dali, Lin'an and Yongchang). Commercial trade was very prosperous then and the city's business classes were formed. Various types of halls established by businessmen groups from all over China. The Guildhall safeguarded the interests of merchants in all parts of Yongchang, promoted the prosperity of Yongchang's commodity economy, and promoted Yongchang became the commercial center for foreign trade. It is the embryonic form of Baoshan Guildhall today.
\end{abstract}

\section{Introduction}

The commercial trade of Yongchang has always been prosperous, which is inseparable with Yongchang's geographical location. There is the Lancang River to the east of Yongchang, the Nu River to the west, and the broad Pingbazi with abundant natural resources in the middle, which is the key thoroughfare to South Asian countries like Myanmar and India. The rise of Yongchang Guildhall of the Qing Dynasty was the product of the social and economic development at that time. The population of Yongchang in the Qing Dynasty increased greatly with the concentration of urban population and the formation of commercialized cities, which made Yongchang become one of the few commercial metropolises in the province at that time.

\section{Establishments of Guildhall around Yongchang}

In the case of urban economic development, business and culture was prosperous in Yongchang, business of businessmen in the mainland of Yongchang became profitable. At the same time, with the increase of the circulation of commodities, the prosperity of the commodity economy, the power of a single businessman and the original commercial organization can no longer meet the ever-expanding demand for commodity trade, only by combining the capital, manpower and material resources of a single businessman for profit Alliance can organize the long-distance sale of commodities. In order to adapt to the ever-expanding commercial trade, an organization with a system was needed to be established, then Guildhall came into being. There were two counties in Yongchang Prefecture in the Qing Dynasty, which included Baoshan County and Yongping County with two Guildhall: Teng-Yue Hall and Long-Ling Hall. Guildhall settings are as follows:

\subsection{The Guildhall of Baoshan County}

There were ten Guildhall in Baoshan County,involving Hubei, Hunan, Sichuan, Jiangxi, Yunnan provinces. The Guildhalls were concentrated in the commercial area of Baoshan County. In the middle of the city,there was Xiaogong Shrine of Jiangxi Guildhall in Xiao Temple Street(now part of the Lan Cheng Road), 2 Zhaowu Shrines of Jiangxi Fuzhou Hall. In the South of the city,there was Lvzu Building, Amitayus Buddha Temple of Hu-guang Hall and Tengyang Hall of Teng-yue. In the east of the city, there was Taibao Foothills,including Chuanzhu Palace of Sichuan Hall, White Crane Concept of Dali Guildhall,Heyun Temple of Dali Heqing Guildhall, Double Crane Concept of Dali Shishu Hall and Yidong Guildhall in the east of Yunnan Province. Most of these halls were built 
during the Shunzhi and Xianfeng years of the Qing Dynasty. During the period of the same clan and the war, most of these halls were damaged. Until the reign of Emperor Guangxu, there were 5 ruined Halls, including Amitayus Buddha Temple,Sichuan Hall, 2 Jiangxi Guildhalls and Tengyang Hall had been restored or rebuilt. Baoshan County Hall can be built or rebuilt is closely related to the prosperity and development of business there.

\subsection{Guildhall of Teng Yue Hall}

Teng Yue Hall is directly bordering Myanmar, and people from land to Myanmar must go through Teng Yue, which was trade center for the distribution of goods for Myanmar and China,with so many nationalities and merchants gathered, Teng Yue Hall was an important distribution for the whole hall area. There were less 3 halls in the city of Teng Yue Hall in Qing Dynasty, including 1 Fujian Hall and 2 Jiangxi Guildhall. There were two halls of Wubao Street in the South of the city of Teng Yue Hall. The new Jiangxi Guildhall was built in Liubao Street. The three halls were constructed during the reign of Emperor Kangxi in the early Qing Dynasty. During the war of Xianfeng, most of the halls in the city were damaged. After that, there were 5 halls, including Guizhou Hall, Sanjian Hall, Sanchu Hall, Xishu Hall and Fujian Hall, which were mainly in the east and south of the city. The documents did not record their detailed construction time, but they appear in the Guangxu years compiled local chronicles.

From this we can see that in and out of the city of Teng Yue, there were at least 8 fellow commercial centers in the Qing Dynasty, which was almost the same as the number in Baoshan County at that time, reflecting the establishment of the Teng Yue Hall as an important commercial port in the southwestern border of China. With its developed and dense hall,which is an important area for commercial development in Yunnan. At the end of the Qing Dynasty, the commercial area of Teng Yue Hall City expanded from the south gate of the inner city. There were numerous shops in the streets of the eastern area. Many fellow country hall and industry guilds was scattered in these places, which made a scene of prosperity.

\subsection{The Guildhall of Longling Hall}

Longling is situated in Burma Boulevard with convenient traffic,which has Baoshan at the east and connected with the Teng-Yue in the west. The land of Longling Hall is barren and lack of supplies, all the goods are trafficked by traders from outside the country, and merchants also sell Myanmar's ivory, amber, crystal and other goods to Longling. This area has been producing soil, mercury,the merchants came there to buy vendors, gathered here and built halls. There were 5 Guildhall built in Longling Hall, including the Xiaogong Shrine built by the guests of Jiangxi Province, the Zhong Lie Ancestral Hall built by the guests of Guizhou, the Amitayus Buddha Temple constructed by the the guests of Huguang ,Chuanzhu Temple built by the citizens of Sichuan, and the Fortune Temple of Snshu Guildhall of Dali.

\subsection{The Guildhall of Yongping County}

There were two Guildhall were built in Yongping County,the first one was Jiangxi Guildhall in the south of the county. Another Guildhall was the Amitayus Buddha Temple built by Huguang residents during the reign of Emperor Kangxi, and it was ruined by the war and then rebuilt during the Guangxu period.

There were 25 recorded Guildhall in Yongchang at that time, and 11 halls' specific construction time can be studied, were built before the war of Xian Year. The establishment of Yongchang Hall was benefited from the commercial progress of Yongchang Hall. Both Baoshan and Tengchong were located along the Boulevard of Burma and Yunnan. The prosperity of the Burmese and Yunnan trade in the Qing Dynasty made the commerce in these two areas more prosperous. Although prosperity of commerce in Longling Hall, Yongping County was less than the prosperity of Baoshan and Tengchong, it also made some development. 


\section{Yongchang Commercial Center's internal organization and management}

With the progress and prosperity of a commercial economy, Guildhalls have been all over the Yongchang halls and counties. Jiangxi Guildhall, Huguang Guildhall, Sichuan Guildhall, Dali Guildhall have in all parts, into a network model of progress, all over the city and become a landmark. The Guildhall established economic organizations by way of association and took the relationship of fellow countrymen as the organizing principle and the Temple as a fixed office place and formulated the relevant rules and regulations to form a gradually institutionalized and standardized Guildhall.

\subsection{Members of the guildhall organization}

Because fellow country guildhall takes geographical relationship as a link to attract members, so the fellow relationship is the principle of fellow members, that members must be fellow. Fellow members of the guildhall are mainly people from different social classes in the same province. We can divide it into three broad categories. The first category is officials, which are mainly for all levels of literary and military officials.

\subsection{Economic sources of guildhall}

The economy of guildhall includes chattels (capital, food, etc.) and real estate (houses, land) formed by the club through diverse channels. Guildhall is a fellow or college group organization. The construction, worship, singing activities and the life of the temple monks in the Guildhall are all shared by the members of the temple. They also need to organize their own independent economic sources and mode of operation. Since the Guildhall is a non-governmental organization formed spontaneously, in general, construction funds of the Guildhall and other funds are collected by the organizations themselves, and the government generally does not provide any funding for long-term funding. Hall of funding sources mainly include the following:

First, pledging channels. Pledging is a major channel for the formation of funds in the guildhall. The establishment of most halls and the construction of funds are all raised through this channel.

Second, pumping channels. Pumping, that is, pump a certain percentage of the amount of money from the turnover of the Guildhall members as the hall construction funds or maintenance funds.

Third, members violations fine channel. For example, there is a record that the Guildhall settled the dispute. When there was a dispute between foreign businessmen in the hall, they must go to the hall to hold the assessment firstly. The plaintiff and the defendant all must pay 1,000 coins, and the money of the one winning will be referred back. The losing one will pay the money to the hall for daily routine expenses.

Fourth, other channels. The government allocated and received the matching family back home bequests, receives gifts, rental income, but also the funds sources of Guildhall. Part of the land of the hall. Funding is allocated by government officials. The government distributed land, funds, which are because some government officials are in the same hall, but this method is rare. The gift is the hall for the idol, or as a temple, or hosting a banquet dinner guests presented, which is relying on rental income.

\subsection{Organization and rules management of Guildhall}

The establishment of any corporate body, written or unwritten rules and regulations, is the basis upon which the internal management of the organization can proceed smoothly. Guildhall organizations also have internal management rules and regulations, which are set out in the Guildhall or the Guildhall inscribed in the hall. These regulations have different contents.

There is a council or board of directors within the Yongchang Guildhall in the Qing Dynasty. There are perhaps one or more first incumbents and live-in monks. They are in charge of executing and handling the peculiar affairs of the guildhall and are also the leaders of the guildhall. The First Incumbents of the Guildhall, the Prime Minister or general director is generally elected democratically through The General Assembly during the election, they need both ability and integrity, fair and honest, and their term of office is unlimited.

The other members of the internal code of conduct also have a detailed day-to-day rules, and there 
are four regulations engraved on the monument in Yongchang Hall: 1. Settle dispute, 2. Reorganize regulation and system, 3.Vitalize regulations and 4 . Reiterate old system to constrain members. They require members to get up in the morning to clean up, reorganize the house, and they are not allowed to go out, unless reveal to the treasurer before leaving. Members are required to register their account clearly at night. No Smoking, alcohol, gambling, troubling, etc., if someone violated, then he will be punished. If both parties have disputes, they must first go to the hall to find accommodation and reconciliation, and they are not allowed to sue on their own will. If members do not comply with the rules of the Hall, submit their own proceedings, they will be called by the Hall abbot of the Temple of Justice.

\section{Functions of Yongchang Guildhall}

Guildhall was set at the beginning, only for Peerage's birthday celebration to enjoy the viewing place at four seasons, and then for fellows to contact. They set the regulations, aside fields, settle dispute, vitalize alms, master market situation, negotiate a deal, with a variety of important functions.

\subsection{The political functions of Guildhall}

Under the leadership of the guest chef, the Guildhall is engaged in the affairs of safeguarding the interests of fellow villagers, mediating the feudal economy and family disputes. In early Spring, each year, fellow officials have to get to the guildhall to worship, watch the drama and discuss the friendship. Whenever a fellow town meets. The patriarch will summarize the annual government affairs. Hall sometimes becomes an essential place for external entertainment activities. In addition to regular meetings, sacrificial rituals and donations, the party also develop recreational and diplomatic projects such as singing and dancing, and sometimes became a prominent feast of prefectures in the county hall.

\subsection{The economic functions of Guildhall}

In addition to worship God, banquet, Guildhall also serve for the development of commodity economy. Merchants can negotiate trade rules through the guildhall and regulate the order of transactions so as to protect the interests of businessmen. In the accumulation of business capital, access to business information, reduce transaction costs and risks, engages in business talks and other aspects of the vital functions. Some of the more powerful Guildhall also have more pavilions on their own, but also directly involved in some commercial activities. In addition to a place, ancestral temple, stage, Guildhall often also have built rooms for fellow merchants to live and store goods.

\subsection{Religious and cultural functions of Guildhall}

The Guildhall building was originally worship temples for fellow villagers has a common virtue of the township god devout belief, and then condensed into the hall organization. The prehistoric people's belief in the gods on the one hand believed that the gods could bless and shelter people from all kinds of risks. On the other hand, in order to obtain the protection of the gods, they gave up some evil ideas and played the role of restraining people's everyday behavior. Hall is the place for worshiping the gods, and gods are binding on behaviors of fellow citizens, so this binding, Xiaogong, he is a country squire who is generally believed in by Jiangxi citizens. Jiangxi merchants gave Xiaogong a legend that saved businessmen from water and fire, making him a god of protection for businessmen in Jiangxi. In addition, businessmen choose fellow alliance for common language, common customs, which not only can make each further exchanges and cooperation easier than the natives, but also help to supervise and constrain the conduct of businessmen. The fellow relationship can narrow the distance between officials, businessmen and all sectors of labor by recruiting them into the hall at the same time. Merchants can obtain asylum of officials and can also cooperate with their fellow tradesmen and workers. 


\section{Conclusion}

Guildhall is one of the main carriers for the development of Yongchang's trade. They use the Guildhall as a link between the Mainland and South Asia to regulate the presence of the market and facilitate the circulation of commodities, which directly promote the development of trade between the mainland and its neighboring areas. Businessmen and travelers from Sichuan bring Shu cloth, Shu Jin to Yongchang's firm, and then sell to Myanmar and bring exceptional skills of handicraft industry back to Yongchang. At the same time, merchants made large-scale development of cotton produced from Myanmar and hired them for planting and selling them to the mainland for sale when they were finished harvesting. Traders also trafficked sea salt from Myanmar to Sanxuan Liuwei which is belong to Yongchang, which made ethnic areas also involved in the market. Tengchong is not just bordering Burma, but since the end of the Sino-Burma War, the two sides have opened up trade and all kinds of commodities have been traded in Tengchong City to form a new commercial trading area and a residential area for residents. Merchants gathered there, and department stores are numerous, the place gradually developed into a trade center for the distribution of goods from Myanmar, affecting both at home and abroad. Longling is also engaged in the economic development of overseas trade. Merchants from Yunnan Province transported goods from Tengchong and Longling to New Street (now Bammo, Burma) and Lao Guan Tun (Yunlin) to various parts of Burma along the Irrawaddy, Myanmar caravans went upstream to Yiu Kiang and landed at Lao Guantun and Xinjie Take the land into Yunnan.

At the same time, we can note that the concept of local community in commercial centers has been preserved for a long period of time. The strong cohesion within communities, the role of community groups in the society, and the social stability and economic and cultural exchanges and development has been somewhat negatively affected. Now Baoshan in Yunnan Province also has Tengyang Hall, Sichuan Hall, Dali Guildhall, Qidong Hall and other sites, but the site has gradually been destroyed, there are still Zhejiang, Anhui, Fujian, Guangdong, Hunan, Sichuan and Chongqing in Baoshan Guildhallin Baoshan commercial development and trade as a non-governmental commercial organizations still play a very important role.

\section{References}

[1] Longyang District of Baoshan City Commission compiled Longyang District, Baoshan City, CPPCC historical materials fourteenth series. Longyang inscriptions on stone, Xu Hongqin Point School, Yunnan Art Publishing Press, 2005.

[2] Qing Liu Yu Ke editors, Xu Hongqin Point School Guangxu Yongchang Fu Zhi, internal information, printed in 2007. 